\title{
Chronic urticaria: the first visit in a specialized unit
}

\author{
Camila Teles Machado Pereira ${ }^{* *}$, Barbara M Aquino ${ }^{1}$, Fernanda Cabral Cardoso Hardt', Luis Felipe Ensina ${ }^{1}$, \\ Inês Cristina Camelo Nunes ${ }^{1}$, Dirceu Sole ${ }^{2}$ \\ From 3rd WAO International Scientific Conference (WISC) 2014 \\ Rio de Janeiro, Brazil. 6-9 December 2014
}

\section{Background}

The aim of this study was to evaluate the clinical profile of patients with chronic urticaria $(\mathrm{CU})$ at first visit in a specialized CU unit.

\section{Methods}

Cross-sectional study of patients seen from January/2012 to June/2014. Patients diagnosed with acute urticaria $(n=5)$ were excluded.

\section{Results}

Among the $50 \mathrm{CU}$ patients, $70 \%$ were female. The mean age at the consultation was 33 years, but the mean age of symptoms onset was 15.3 years. Fifty one percent referred only urticaria, $44 \%$ referred urticaria associated with angioedema and 5\% presented isolated angioedema. Besides itching, 6 patients complained of burning (12\%) and 2 of pain (4\%). Frequency of wheals was daily in $33 \%$, weekly in $36 \%$ and monthly in $31 \%$. At first visit, Urticaria Activity Score was verified in 24 patients, resulting $>3$ in half of them. The most associated atopic disease was rhinitis (45\%). Many patients mentioned triggers as medicines (33\%), food (23\%), stress (17\%), viral infection (8\%) and physical agents (16\%). Only $6 \%$ had thyroidopathy. As previous treatment a significant amount of patients received sedating antihistamines (AH) $(36 \%)$ or oral corticosteroids (24\%), with partial improvement in $65 \%$ and complete improvement in $29 \%$. Dermographism was positive in $91 \%$ of the patients tested (20/22). One of them was diagnosed with cholinergic urticaria and another one with delayed pressure urticaria.

\section{Conclusions}

The higher prevalence of $\mathrm{CU}$ was in middle-aged women. However, strong association with thyroiditis

${ }^{1}$ Federal University of Sao Paulo, Brazil

Full list of author information is available at the end of the article was not found. Sedating AH and corticosteroids are still the most prescribed drugs.

\section{Authors' details}

${ }^{1}$ Federal University of Sao Paulo, Brazil. ${ }^{2}$ Brazilian Society, Brazil.

Published: 8 April 2015

doi:10.1186/1939-4551-8-S1-A125

Cite this article as: Machado Pereira et al:: Chronic urticaria: the first visit

in a specialized unit. World Allergy Organization Journal 2015 8(Suppl 1):A125.
Submit your next manuscript to BioMed Central and take full advantage of:

- Convenient online submission

- Thorough peer review

- No space constraints or color figure charges

- Immediate publication on acceptance

- Inclusion in PubMed, CAS, Scopus and Google Scholar

- Research which is freely available for redistribution
() Biomed Central
C Biomed Central

(c) 2015 Machado Pereira et al; licensee BioMed Central Ltd. This is an Open Access article distributed under the terms of the Creative Commons Attribution License (http://creativecommons.org/licenses/by/4.0), which permits unrestricted use, distribution, and reproduction in any medium, provided the original work is properly cited. The Creative Commons Public Domain Dedication waiver (http://creativecommons.org/publicdomain/zero/1.0/) applies to the data made available in this article, unless otherwise stated. 